\title{
Effects of Fatty Acid Oxidation Products (Green Odor) on Rumen Bacterial Populations and Lipid Metabolism In Vitro
}

\author{
M. R. F. Lee, ${ }^{* 1}$ S. A. Huws,${ }^{*}$ N. D. Scollan, ${ }^{*}$ and R. J. Dewhurst $†$ \\ *Institute of Grassland and Environmental Research, Plas Gogerddan, Aberystwyth, SY23 3EB, United Kingdom \\ †Agriculture and Life Sciences Division, Lincoln University, Canterbury, New Zealand
}

\begin{abstract}
This study investigated the effects of green odor fatty acid oxidation products (FAOP) from cut grass on lipid metabolism and microbial ecology using in vitro incubations of rumen microorganisms. These compounds have antimicrobial roles in plant defense, and we hypothesized that they may influence rumen lipid metabolism. Further, they may partially explain the higher levels of conjugated linoleic acid cis-9, trans-11 in milk from cows grazing pasture. The first of 2 batch culture experiments screened 6 FAOP ( 1 hydroperoxide, 3 aldehydes, 1 ketone, and 1 alcohol) for effects on lipid profile, and in particular $\mathrm{C}_{18}$ polyunsaturated fatty acid biohydrogenation. Experiment 2 used the most potent FAOP to determine effects of varying concentrations and identify relationships with effects on microbial ecology. Batch cultures contained anaerobic buffer, rumen liquor, and FAOP to a final concentration of $100 \mu M$ for experiment 1. Triplicates for each compound and controls (water addition) were incubated at $39^{\circ} \mathrm{C}$ for $6 \mathrm{~h}$. The hydroperoxide (1,2-dimethylethyl hydroperoxide, 1,2-DMEH) and the long chain aldehyde (trans-2 decenal) had the largest effects on lipid metabolism with significant increases in $\mathrm{C}_{18: 0}$ and $\mathrm{C}_{18: 1}$ trans and reductions in $\mathrm{C}_{12: 0}$, $\mathrm{C}_{14: 0}, \mathrm{C}_{16: 0}, \mathrm{C}_{18: 1}$ cis, $\mathrm{C}_{18: 2 \mathrm{n}-6}, \mathrm{C}_{18: 3 \mathrm{n}-3}, \mathrm{C}_{20: 0}$ and total branch and odd chain fatty acids compared with the control. This was associated with significantly higher biohydrogenation of $\mathrm{C}_{18}$ polyunsaturated fatty acid. In experiment 2, 1,2-DMEH was incubated at 50, 100, and $200 \mu M$ for 2,6 , and $24 \mathrm{~h}$. Increasing 1,2-DMEH concentration resulted in a significant linear increase in $\mathrm{C}_{18: 1}$ trans-10, trans-11, conjugated linoleic acid, and $\mathrm{C}_{18: 0}$ and a linear decrease in $\mathrm{C}_{18: 2 \mathrm{n}-6}$ and $\mathrm{C}_{18: 3 \mathrm{n}-3}$, although the scale of this response declined with time. Microbial profiling techniques showed that 1,2-DMEH at concentrations of 100 and $200 \mu M$ changed the microbial community from as early as $2 \mathrm{~h}$ after addition,
\end{abstract}

Received March 12, 2007.

Accepted April 17, 2007.

${ }^{1}$ Corresponding author: michael.lee@bbsrc.ac.uk though microbial biomass remained similar. These preliminary studies have shown that FAOP can alter fatty acid biohydrogenation in the rumen. This change was associated with changes in the microbial population that were detected through DNA and branched- and odd-chain fatty acid profiling approaches.

Key words: fatty acid oxidation product, conjugated linoleic acid, $\mathrm{C}_{18: 1}$ trans-11, rumen bacteria

\section{INTRODUCTION}

A growing number of experiments show higher concentrations of cis-9, trans-11 conjugated linoleic acid (CLA) in milk from cows grazing fresh pastures than in milk produced by cows offered conserved forages (Dewhurst et al., 2006). Furthermore, Offer (2002) showed that a similar depression in milk fat CLA cis9 , trans-11 could be achieved if the grass was simply cut and fed after a short wilt.

This experiment was a preliminary investigation of one mechanism that may explain some of these differences. A range of distinctive green odor compounds are released from plant cells when damaged, whether through animal herbivory, mechanical cutting, or microbial invasion. Plant lipases release nonesterified $\mathrm{C}_{18}$ polyunsaturated fatty acids (PUFA; $\mathrm{C}_{18: 3 n-3}$ and $\mathrm{C}_{18: 2 \mathrm{n}-6}$ ) from damaged membranes (Thomas, 1986), and these are rapidly converted to hydroperoxy PUFA by the action of lipoxygenases (Feussner and Wasternack, 2002). The hydroperoxy PUFA are further catabolized to yield a range of fatty acid oxidation products (FAOP), such as leaf aldehydes and alcohols (Kirstine et al., 1998), which give rise to the distinctive green odor. The function of these compounds during cell damage is to act as signaling compounds between plants (Creelman and Mullet, 1997) or toward predators (Thaler, 1999), development of hypersensitive cell death (Rusterucci et al., 1999), or antimicrobial activity (Strobel et al., 2001, Cho et al., 2004). The basis of this study was that this antimicrobial activity may also affect microbial metabolism in the rumen of grazing animals.

Dietary PUFA are rapidly hydrogenated by the rumen bacteria, resulting in the production of saturated 
fatty acids (principally $\mathrm{C}_{18: 0}$ ), but also the formation of several intermediates: $\mathrm{C}_{18: 1}$ trans, $\mathrm{C}_{18: 1}$ cis, conjugated $\mathrm{C}_{18: 2}$ (CLA), and nonconjugated $\mathrm{C}_{18: 2}$ isomers (Demeyer and Doreau, 1999). The predominant $\mathrm{C}_{18: 1}$ trans-11 can be converted into CLA cis-9, trans-11 by the enzyme $\Delta^{9}$-desaturase in the mammary gland and adipose tissue, and it is thought that this route forms the majority of CLA cis-9, trans-11 found in ruminant meat and milk (Piperova et al., 2002). This isomer of CLA has been shown to be important in human health in numerous animal models (Lock and Bauman, 2004). Kemp and Lander (1984) grouped the bacteria involved in the biohydrogenation pathways into 2 groups: group $\mathrm{A}$ bacteria are able to hydrogenate $\mathrm{C}_{18: 2 \mathrm{n}-6}$ and $\mathrm{C}_{18: 2 \mathrm{n}-3}$ to $\mathrm{C}_{18: 1}$ trans-11, whereas group $\mathrm{B}$ bacteria are able to hydrogenate $\mathrm{C}_{18: 1}$ trans- 11 to $\mathrm{C}_{18: 0}$.

This study investigated the effects of a number of FAOP on lipid metabolism, with particular emphasis on $\mathrm{C}_{18}$ PUFA biohydrogenation and formation of intermediates $\left(\mathrm{C}_{18: 1}\right.$ trans-11 and CLA cis-9, trans-11) during in vitro batch cultures. The most potent FAOP was then used in a titration experiment to determine if the marked changes in lipid metabolism were related to concentration of the FAOP and if there were any changes in the microbial ecology.

\section{MATERIALS AND METHODS}

\section{Experimental Design}

Two in vitro batch culture experiments were carried out to test the effect of a range of FAOP on $\mathrm{C}_{18}$ PUFA biohydrogenation and intermediate formation. The first study evaluated a range of FAOP, whereas the second used the most potent FAOP in a titration study to determine the effect of concentration of the FAOP and with molecular profiling if there were any changes in microbial ecology.

\section{Experiment 1}

Six FAOP were chosen to test the hypothesis: cis-2hexenol (C2H), hexanal (HL), trans-2-hexenal (T2H), trans-2 decenal (T2D), 3-buten-2-one (3B), and 1-2-dimethylethyl hydroperoxide (1,2-DMEH). The C2H, HL, and $\mathrm{T} 2 \mathrm{H}$ are alcohols and aldehydes that are typically found in the green odor (Hatanaka, 1993). Longer chain aldehydes can also be produced by plants through enzyme activity; T2D is an example of these. Aldehydes and hydroperoxides are also found in the green odor of plants and were represented by $3 \mathrm{~B}$ and 1,2-DMEH, respectively. Although these compounds are not typically found in the green odor, they have similar properties to more common green odor ketones and hydroperoxides (Kepler et al., 1970; Kirstine et al., 1998). All compounds were of the highest purity and supplied by Acros Organics (Geel, Belgium).

The following solutions were made up: buffer $(0.4 \%$ $\left.\mathrm{NH}_{4} \mathrm{HCO}_{3}, \quad 3.5 \% \quad \mathrm{NaHCO}_{3}\right)$; macromineral $(0.95 \%$ $\mathrm{Na}_{2} \mathrm{HPO}_{4} \cdot 12 \mathrm{H}_{2} \mathrm{O}, \quad 0.62 \% \quad \mathrm{KH}_{2} \mathrm{PO}_{4}, \quad 0.06 \% \quad \mathrm{MgSO}_{4}$. $\left.7 \mathrm{H}_{2} \mathrm{O}\right)$; micromineral $\left(13.2 \% \quad \mathrm{CaCl}_{2} \cdot 2 \mathrm{H}_{2} \mathrm{O}, \quad 10.0 \%\right.$ $\mathrm{MnCl}_{2} \cdot 4 \mathrm{H}_{2} \mathrm{O}, 1.0 \% \mathrm{CoCl}_{2} \cdot 6 \mathrm{H}_{2} \mathrm{O}, 8.0 \% \mathrm{FeCl}_{3} \cdot 6 \mathrm{H}_{2} \mathrm{O}$ ); and resazurin $(0.01 \%$ resazurin redox indicator). These solutions were then combined to make up the incubation media at a ratio of 2:1:1 deionized water: buffer: macromineral. Micromineral $(0.1 \mathrm{~mL} / \mathrm{L})$ and reazurin $(1 \mathrm{~mL} /$ L) were added, and the mixture was then gassed with $\mathrm{CO}_{2}$ until anaerobic as indicated by the redox indicator. Anaerobic incubation media $(10 \mathrm{~mL})$ were then dispensed into 21 incubation bottles (triplicates of each FAOP to a final concentration of $100 \mu M$ along with triplicates of a water control). The concentration of FAOP was derived from the typical release rate of FAOP from cut grass $(0.3 \mathrm{mmol} / \mathrm{kg}$ of fresh weight $/ \mathrm{min}$; Hatanaka, 1993) and the average DM of the rumen contents of a forage-fed dairy cow (12\%, Dewhurst et al., 2003). One gram of lyophilized and ground grass silage was accurately weighed out into each incubation bottle, containing the $100 \mu M$ of FAOP or water (control) and anaerobic media. The headspace of each bottle was gassed with $\mathrm{CO}_{2}$, sealed, and left to equilibrate to temperature $\left(39^{\circ} \mathrm{C}\right)$ in an incubator. Hand-squeezed rumen liquor was collected from 2 grass silage-fed fistulated cows and immediately transported to the laboratory in a preheated vacuum flask. Incubation bottles were inoculated with $10 \mathrm{~mL}$ of rumen fluid under $\mathrm{CO}_{2}$ and returned to the incubator at $39^{\circ} \mathrm{C}$ in the dark. The incubation period was set at $6 \mathrm{~h}$, as an optimal time to maximize amounts of biohydrogenation intermediates (Wasowska et al., 2006). A sample of the grass silage and rumen inoculum were analyzed for freeze-DM and fatty acids to represent the initial time point $(0 \mathrm{~h})$ and used for the calculation of $\mathrm{C}_{18}$ PUFA biohydrogenation.

At the end of the incubation $(6 \mathrm{~h})$, the bottles were removed from the incubator and treated with $25 \mathrm{~mL}$ of isopropanol: chloroform (1:1; vol/vol) along with $1 \mathrm{~mL}$ of internal standard ( $2.5 \mathrm{mg}$ of $\mathrm{C}_{19: 0} / \mathrm{mL}$ of chloroform) and extracted as described by Lee et al. (2004). Lipid in the inoculum sample was extracted in triplicate from $1 \mathrm{~g}$ of lyophilized solid using $5 \mathrm{~mL}$ of a mixture of chloroform: methanol $(2: 1, \mathrm{vol} / \mathrm{vol})$ with $100 \mu \mathrm{L}$ of internal standard solution (15 mg of $\mathrm{C}_{21: 0}$ methyl ester $/ \mathrm{mL}$ of chloroform). Extracts were evaporated to dryness at $50^{\circ} \mathrm{C}$ under a continuous flow of $\mathrm{N}_{2}$ and redissolved in $1 \mathrm{~mL}$ of hexane. Conversion to fatty acid methyl esters (FAME) was by base-acid catalyzed transesterification with methanolic $\mathrm{NaOH}(5 M ; 15 \mathrm{~min})$ followed by methanolic $\mathrm{HCl}(5 \% ; 1 \mathrm{~h})$ heating at $50^{\circ} \mathrm{C}$ according to Kramer and Zhou (2001). The fatty acids in the silage 
Table 1. Major fatty acids (percentage of the total fatty acid content) in vessels after incubation with or without $100 \mu M$ of a particular fatty acid oxidation product (experiment 1)

\begin{tabular}{lcccccccl}
\hline Item & $\mathrm{C} 2 \mathrm{H}$ & $\mathrm{HL}$ & $3 \mathrm{~B}$ & $1,2-\mathrm{DMEH}$ & $\mathrm{T} 2 \mathrm{D}$ & $\mathrm{T} 2 \mathrm{H}$ & Control & SED $^{1}$ \\
\hline $\mathrm{C}_{12: 0}$ & 0.24 & 0.26 & 0.24 & $0.20^{\mathrm{b}}$ & $0.17^{\mathrm{b}}$ & 0.24 & 0.27 & 0.024 \\
$\mathrm{C}_{14: 0}$ & 0.89 & 0.98 & 0.92 & $0.73^{\mathrm{b}}$ & $0.65^{\mathrm{b}}$ & 0.92 & 1.01 & 0.090 \\
$\mathrm{C}_{16: 0}$ & $14.7^{\mathrm{b}}$ & 15.9 & $15.3^{\mathrm{b}}$ & $13.3^{\mathrm{b}}$ & $13.9^{\mathrm{b}}$ & 16.2 & 17.1 & 0.62 \\
$\mathrm{C}_{16: 1}$ cis & 0.11 & 0.15 & 0.12 & 0.10 & 0.12 & 0.14 & 0.15 & 0.020 \\
$\mathrm{C}_{18: 0}$ & $51.3^{\mathrm{a}}$ & 46.7 & 49.5 & $54.5^{\mathrm{a}}$ & $53.2^{\mathrm{a}}$ & 47.0 & 45.6 & 2.06 \\
$\mathrm{C}_{18: 1}$ trans $^{2}$ & $9.00^{\mathrm{a}}$ & 8.51 & $9.01^{\mathrm{a}}$ & $9.83^{\mathrm{a}}$ & $9.04^{\mathrm{a}}$ & 8.64 & 8.30 & 0.292 \\
$\mathrm{C}_{18: 1}$ cis $^{2}$ & $2.73^{\mathrm{b}}$ & 3.23 & 3.02 & $2.45^{\mathrm{b}}$ & $2.87^{\mathrm{b}}$ & 3.29 & 3.41 & 0.162 \\
$\mathrm{C}_{18: 2 \mathrm{n}-6}$ & 3.30 & 4.21 & 3.53 & $2.74^{\mathrm{b}}$ & $2.91^{\mathrm{b}}$ & 4.05 & 4.25 & 0.446 \\
$\mathrm{C}_{18: 3 n-3}$ & 6.91 & 9.07 & 7.35 & $5.68^{\mathrm{b}}$ & $6.23^{\mathrm{b}}$ & 8.66 & 9.00 & 1.065 \\
$\mathrm{CLA}^{2}$ & 0.32 & 0.31 & 0.33 & $0.42^{\mathrm{a}}$ & 0.35 & 0.32 & 0.35 & 0.021 \\
$\mathrm{C}_{20: 0}$ & $0.69^{\mathrm{b}}$ & 0.74 & 0.72 & $0.64^{\mathrm{b}}$ & $0.60^{\mathrm{b}}$ & 0.72 & 0.78 & 0.038 \\
\hline
\end{tabular}

${ }^{a}$ Values are greater $(P<0.05)$ than the control.

${ }^{b}$ Values are less $(P<0.05)$ than the control.

${ }^{1} \mathrm{SED}=$ standard error of the differences of means.

${ }^{2}$ Sum of all isomers. $\mathrm{C} 2 \mathrm{H}=c i s$-2 hexen-1-ol; $\mathrm{HL}=$ hexenal; 3B = 3-buten-2-one; 1,2-DMEH = 1,2-dimethylethyl hydroperoxide; T2D = trans -2 decenal; $\mathrm{T} 2 \mathrm{H}=$ trans -2 hexenal. $\mathrm{CLA}=$ conjugated linoleic acid .

were extracted using a one-step extraction-transesterification procedure described by Sukhija and Palmquist (1988). The FAME were analyzed by gas chromatography on a CP-Select chemically bonded for FAME column $(100 \mathrm{~m} \times 0.25 \mathrm{~mm}$ I.D., Varian Inc., Palo Alto, CA) with split injection (1:50). Peaks were identified from external standards (ME61, Larodan fine chemicals, Malmo, Sweden; S37, Supelco, Poole, Dorset, UK; CLA, Matreya, Philadelphia, PA) and quantified using the internal standards $\left(\mathrm{C}_{19: 0}\right.$ for the incubations and $\mathrm{C}_{21: 0}$ for the inoculum and grass silage).

\section{Experiment 2}

Anaerobic buffer was made up as described for experiment 1 and $25 \mathrm{~mL}$ dispensed into 18 bottles. The most potent FAOP in the first experiment was $1,2-\mathrm{DMEH}$, and this was used at 4 concentrations: $0,50,100$, and $200 \mu M$ for 3 time points: 2,6 , and $24 \mathrm{~h}$; each concentration and time point was replicated 3 times. Two and one-half grams of lyophilized and ground grass silage was weighed into each incubation bottle. These were inoculated with $25 \mathrm{~mL}$ of rumen fluid under $\mathrm{CO}_{2}$ (obtained as for experiment 1 ). The incubation bottles were then incubated at $39^{\circ} \mathrm{C}$ in the dark.

At the end of each incubation time point $(2,6$, and $24 \mathrm{~h}$ ) the respective bottles were removed from the incubator and immediately frozen using liquid $\mathrm{N}_{2}$ and stored at $-20^{\circ} \mathrm{C}$ prior to being lyophilized. The lyophilized samples were ground and split in 2 with half for fatty acid analysis and half for molecular profiling. Lipid was extracted from 1-g samples of lyophilized material after adding $1 \mathrm{~mL}$ of internal standard (2.5 $\mathrm{mg}$ of $\mathrm{C}_{19: 0} / \mathrm{mL}$ of chloroform) using $3 \times 5 \mathrm{~mL}$ of chloroform:methanol $(2: 1 ; \mathrm{vol} / \mathrm{vol})$. The extracts were dried under $\mathrm{N}_{2}$ in a water bath at $50^{\circ} \mathrm{C}$, methylated, and run on GC as described in experiment 1.

Bacterial PCR-denaturation gradient gel electrophoresis (PCR-DGGE) profiling was carried out with selected samples that showed substantial differences in terms of fatty acid profiles (particularly $\mathrm{C}_{18: 1}$ trans -11 and CLA cis-9, trans-11), which may be attributable to changes in the microbial consortia. The DNA was extracted from the lyophilized samples using the FastDNA soil kit (QBiogene, Illkirch, France) according to manufacturers' instructions, but with the slight modification in that bead beating was carried out at $3 \times 30$ $\mathrm{s}$ with 1-min intervals on ice. Amplification of the V68 region of the 16S rRNA gene was carried out with the primer pair F968GC and R1401 (Nübel et al., 1996). All PCR amplifications were performed using a 2720 thermal cycler (Applied Biosystems, Foster City, CA) in $50-\mu \mathrm{L}$ volumes containing $1 \times$ PCR Buffer $(20 \mathrm{mM}$ Tris-HCl, pH 8.4, $50 \mathrm{mM} \mathrm{KCl),} 3 \mathrm{~m} M \mathrm{MgCl}_{2}, 200 \mu M$ deoxynucleoside triphosphates, $500 \mathrm{n} M$ (each primer), and 1.25 U of iTaq DNA polymerase (BioRad Laboratories, Hemel Hempstead, UK). Amplification was an initial denaturation of $95^{\circ} \mathrm{C}$ for $3 \mathrm{~min}$, followed by 35 regular cycles $\left(95^{\circ} \mathrm{C}\right.$ for $30 \mathrm{~s}, 56^{\circ} \mathrm{C}$ for $30 \mathrm{~s}$, and $72^{\circ} \mathrm{C}$ for $1 \mathrm{~min}$ ) and a final extension of $72^{\circ} \mathrm{C}$ for $5 \mathrm{~min}$ (Nübel et al., 1996). After PCR, amplification of products was verified by agarose gel electrophoresis.

The PCR amplicons were loaded onto $6 \%$ polyacrylamide gels with a 35 to $60 \%$ denaturing gradient $[100 \%$ denaturant consisting of $40 \%$ ( $\mathrm{vol} / \mathrm{vol}$ ) deionized formamide and $7 M$ urea] and electrophoresis performed in a DCode system (BioRad Laboratories) as previously described (Heilig et al., 2002). Gels were then stained with silver nitrate (Sanguinetti et al., 1994). Gels were scanned using a GS-710 calibrated imaging densitome- 
Table 2. Branched and odd chain (BOC) fatty acids (percentage of the total fatty acid content) in vessels after incubation with or without $100 \mu M$ of a particular fatty acid oxidation product (experiment 1)

\begin{tabular}{lcccccccc}
\hline Item $^{1}$ & $\mathrm{C} 2 \mathrm{H}$ & $\mathrm{HL}$ & $3 \mathrm{~B}$ & $1,2-\mathrm{DMEH}$ & $\mathrm{T} 2 \mathrm{D}$ & $\mathrm{T} 2 \mathrm{H}$ & Control & SED $^{2}$ \\
\hline $\mathrm{C}_{15: 0}$ Iso & 0.53 & 0.60 & 0.57 & $0.42^{\mathrm{b}}$ & $0.39^{\mathrm{b}}$ & 0.56 & 0.61 & 0.057 \\
$\mathrm{C}_{15: 0}$ Anteiso & 0.88 & 1.04 & 0.98 & $0.66^{\mathrm{b}}$ & $0.67^{\mathrm{b}}$ & 0.99 & 1.05 & 0.101 \\
$\mathrm{C}_{15: 0}$ & 0.94 & 1.02 & 1.00 & $0.82^{\mathrm{b}}$ & $0.80^{\mathrm{b}}$ & 1.01 & 1.06 & 0.060 \\
$\mathrm{C}_{17: 0}$ Iso & $0.22^{\mathrm{b}}$ & 0.25 & 0.24 & $0.20^{\mathrm{b}}$ & $0.22^{\mathrm{b}}$ & 0.24 & 0.25 & 0.012 \\
$\mathrm{C}_{17: 0}$ Anteiso & $0.20^{\mathrm{b}}$ & 0.25 & 0.22 & $0.15^{\mathrm{b}}$ & $0.17^{\mathrm{b}}$ & 0.25 & 0.26 & 0.020 \\
$\mathrm{C}_{17: 0}$ & 0.44 & 0.44 & 0.46 & 0.44 & 0.44 & 0.44 & 0.45 & 0.008 \\
Total BOC fatty acids & 3.21 & 3.60 & 3.47 & $2.69^{\mathrm{b}}$ & $2.69^{\mathrm{b}}$ & 3.49 & 3.68 & 0.178 \\
\hline
\end{tabular}

${ }^{\text {aV }}$ alues are greater $(P<0.05)$ than the control.

${ }^{\mathrm{b}}$ Values are less $(P<0.05)$ than the control.

${ }^{1} \mathrm{C} 2 \mathrm{H}=$ cis-2 hexen-1-ol; $\mathrm{HL}$ = hexenal; 3B = 3-buten-2-one; 1,2-DMEH = 1,2-dimethylethyl hydroperoxide; $\mathrm{T} 2 \mathrm{D}=$ trans -2 decenal; $\mathrm{T} 2 \mathrm{H}=$ trans -2 hexenal

${ }^{2} \mathrm{SED}=$ standard error of the differences of means.

ter (BioRad Laboratories) and the saved image imported into the software package Fingerprinting (BioRad Laboratories) for analysis. Cluster analysis was performed using Dice, with a position tolerance of $0.5 \%$ and optimization parameter of $1 \%$. The binary data generated was used to calculate band number and the Shannon's diversity index (Yu and Morrison, 2004; Gafan et al., 2005).

\section{Statistical Analysis}

All fatty acids for both experiments are reported as a percentage of total fatty acids in the incubations so that the results were not confounded by level of fatty acid within different incubation bottles. Biohydrogenation was calculated as the proportional loss of $\mathrm{C}_{18}$ PUFA from the initial time point $(0 \mathrm{~h}$, analysis of the rumen inoculum and grass silage) to the incubation end point. Statistical difference was inferred by using a Student $t$-test (Payne et al., 2002) to compare the fatty acid composition of the particular FAOP or concentration against the control. In experiment 2 each time point was treated separately with linearity of the response to concentration determined using ANOVA fitted with polynomial contrasts with concentration $(0,50,100$, and 200) as the treatment effect (Payne et al., 2002).

For band number and Shannon-Weiner diversity index data statistical difference was also inferred by using a Student $t$-test (Payne et al., 2002) to compare test data against the control.

\section{RESULTS}

\section{Experiment 1}

The addition of 1,2-DMEH and T2D had the largest effect on the fatty acid proportions in the vessels compared with the control (Table 1) with a significant reduction in $\mathrm{C}_{12: 0}, \mathrm{C}_{14: 0}, \mathrm{C}_{16: 0}, \mathrm{C}_{18: 1}$ cis, $\mathrm{C}_{18: 2 \mathrm{n}-6}, \mathrm{C}_{18: 3 \mathrm{n}-3}$, and
$\mathrm{C}_{20: 0}$. They also produced a significant elevation $(P<$ $0.05)$ in $\mathrm{C}_{18: 0}, \mathrm{C}_{18: 1}$ trans and in the case of 1,2-DMEH total CLA proportions. The addition of $\mathrm{C} 2 \mathrm{H}$ resulted in a reduction in the proportions of $\mathrm{C}_{16: 0}, \mathrm{C}_{18: 1} \mathrm{cis}$, and $\mathrm{C}_{20: 0}$, with an elevation in $\mathrm{C}_{18: 0}$ and $\mathrm{C}_{18: 1}$ trans. The addition of a ketone (3B) resulted in a reduction in $\mathrm{C}_{16: 0}$ and an increase in $\mathrm{C}_{18: 1}$ trans. Both the additions of $\mathrm{HL}$ and $\mathrm{T} 2 \mathrm{H}$ had no effect on the proportions of the major fatty acids compared with the control. The effects of the FAOP on branched- and odd-chain fatty acids (BOC) are shown in Table 2. The 1,2-DMEH and T2D caused significant reductions in the proportions of $\mathrm{C}_{15: 0}$, $\mathrm{C}_{15: 0}$ iso, $\mathrm{C}_{15: 0}$ anteiso, $\mathrm{C}_{17: 0}$ iso, $\mathrm{C}_{17: 0}$ anteiso, and total BOC compared with the control. The only other FAOP that had an effect on $\mathrm{BOC}$ was $\mathrm{C} 2 \mathrm{H}$, which resulted in a significant reduction in $\mathrm{C}_{17: 0}$ iso and $\mathrm{C}_{17: 0}$ anteiso.

The percentage of $\mathrm{C}_{18: 1}$ and CLA isomers and the biohydrogenation values [g of $\mathrm{C}_{18}$ PUFA output $(6 \mathrm{~h}) / \mathrm{g}$ of $\mathrm{C}_{18}$ PUFA input $\left.(0 \mathrm{~h})\right]$ of $\mathrm{C}_{18}$ PUFA are given in Table 3. The 1,2-DMEH and T2D addition resulted in a significant reduction in cis-11 and cis-12, whereas T2D alone reduced trans-10, trans-13 and trans-10, cis12 CLA. The 1,2-DMEH reduced cis-9 and increased the proportions of trans-13 and CLA trans-11, trans-13, whereas both fatty acid oxidation products increased trans-11. The $\mathrm{C} 2 \mathrm{H}$ increased the proportion of trans13 in the vessels but decreased cis-9 and cis-11 compared with the control. The 3B also resulted in a decrease in cis-11 and an increase in trans-10. With the exception of a slight decrease in trans-10, cis-12, HL and $\mathrm{T} 2 \mathrm{H}$ had no effect on the proportions of $\mathrm{C}_{18: 1}$ and CLA isomers in the vessels compared with the control. The 1,2-DMEH and T2D were the only FAOP to affect biohydrogenation, with both causing a significant increase compared with the control.

\section{Experiment 2}

The 1,2-DMEH was used in experiment 2 because it showed the largest differences in lipid metabolism in 
Table 3. $\mathrm{C}_{18: 1}$ isomers and conjugated linoleic acid (CLA) isomers (percentage of the total fatty acid content) and proportional biohydrogenation $(\mathrm{g} / \mathrm{g})$ of $\mathrm{C}_{18}$ polyunsaturated fatty acid after incubation of the vessels with or without $100 \mu M$ of a particular fatty acid oxidation product (experiment 1)

\begin{tabular}{lllllllll}
\hline Item & $\mathrm{C} 2 \mathrm{H}$ & $\mathrm{HL}$ & $3 \mathrm{~B}$ & $1,2-\mathrm{DMEH}$ & $\mathrm{T} 2 \mathrm{D}$ & $\mathrm{T} 2 \mathrm{H}$ & Control & SED $^{1}$ \\
\hline $\mathrm{C}_{18: 1 \text { trans }}$ & & & & & & & & \\
$6 / 7 / 8$ & 0.38 & 0.35 & 0.37 & 0.41 & 0.34 & 0.32 & 0.31 & 0.033 \\
9 & 0.17 & 0.17 & 0.19 & 0.18 & 0.19 & 0.18 & 0.15 & 0.016 \\
10 & 0.38 & 0.35 & $0.40^{\mathrm{a}}$ & 0.37 & $0.30^{\mathrm{b}}$ & 0.36 & 0.35 & 0.022 \\
11 & 6.16 & 6.03 & 6.16 & $6.75^{\mathrm{a}}$ & $6.63^{\mathrm{a}}$ & 6.12 & 5.83 & 0.181 \\
12 & 0.44 & 0.41 & 0.46 & 0.48 & 0.44 & 0.43 & 0.42 & 0.042 \\
$13+$ cis-6 $^{2}$ & $0.83^{\mathrm{a}}$ & 0.62 & 0.76 & $0.94^{\mathrm{a}}$ & $0.48^{\mathrm{b}}$ & 0.62 & 0.65 & 0.067 \\
15 & 0.64 & 0.58 & 0.66 & 0.70 & 0.66 & 0.61 & 0.60 & 0.065 \\
16 & 0.65 & 0.56 & 0.64 & 0.70 & 0.68 & 0.59 & 0.57 & 0.068 \\
$\mathrm{C}_{18: 1}$ cis & & & & & & & & \\
9 & $1.84^{\mathrm{b}}$ & 2.24 & 2.09 & $1.65^{\mathrm{b}}$ & 2.10 & 2.30 & 2.33 & 0.110 \\
11 & 0.30 & 0.34 & $0.31^{\mathrm{b}}$ & $0.27^{\mathrm{b}}$ & $0.28^{\mathrm{b}}$ & 0.35 & 0.38 & 0.026 \\
12 & 0.24 & 0.26 & 0.24 & $0.20^{\mathrm{b}}$ & $0.17^{\mathrm{b}}$ & 0.24 & 0.27 & 0.024 \\
13 & 0.05 & 0.05 & 0.06 & 0.05 & 0.05 & 0.05 & 0.05 & 0.001 \\
$\mathrm{CLA}^{\text {cis-9, trans-11 }}$ & & & & & & & & \\
trans-10, cis-12 & 0.05 & 0.05 & 0.05 & 0.06 & 0.05 & 0.05 & 0.05 & 0.010 \\
trans-9, trans-11 & 0.09 & $0.08^{\mathrm{b}}$ & 0.09 & 0.11 & $0.08^{\mathrm{b}}$ & $0.08^{\mathrm{b}}$ & 0.10 & 0.006 \\
$\quad$ trans-11, trans -13 & 0.04 & 0.04 & 0.04 & 0.05 & 0.04 & 0.04 & 0.05 & 0.006 \\
Biohydrogenation & 0.19 & 0.18 & 0.19 & $0.25^{\mathrm{a}}$ & 0.21 & 0.19 & 0.20 & 0.014 \\
$\mathrm{C}_{18: 2 \mathrm{n}-6}$ & 0.65 & 0.59 & 0.65 & $0.72^{\mathrm{a}}$ & $0.78^{\mathrm{a}}$ & 0.64 & 0.58 & 0.053 \\
$\mathrm{C}_{18: 3 n-3}$ & 0.70 & 0.65 & 0.71 & $0.77^{\mathrm{a}}$ & $0.81^{\mathrm{a}}$ & 0.69 & 0.64 & 0.045 \\
\hline
\end{tabular}

${ }^{a}$ Values are greater $(P<0.05)$ than the control.

${ }^{b}$ Values are less $(P<0.05)$ than the control.

${ }^{1} \mathrm{SED}=$ standard error of the differences of means.

${ }^{2} \mathrm{C}_{18: 1}$ trans-13 and cis-6 coelute and so are reported as a single value; consequently, total $\mathrm{C}_{18: 1}$ trans is slightly overestimated and total $\mathrm{C}_{18: 1}$ cis slightly underestimated. $\mathrm{C} 2 \mathrm{H}=$ cis-2 hexen-1-ol; $\mathrm{HL}=$ hexenal; 3B = 3-buten-2-one; 1,2-DMEH = 1,2-dimethylethyl hydroperoxide; $\mathrm{T} 2 \mathrm{D}=$ trans-2 decenal; $\mathrm{T} 2 \mathrm{H}=$ trans-2 hexenal.

experiment 1 . Tables 4,5 , and 6 show the effects of 1,2 DMEH at 50,100, and $200 \mu M$ against the control without the addition of 1,2-DMEH on $\mathrm{C}_{18}$ and $\mathrm{BOC}$ concentration after 2,6 , and $24 \mathrm{~h}$, respectively. After $2 \mathrm{~h}$ of incubation there was a significant increase in $\mathrm{C}_{18: 0}, \mathrm{C}_{18: 1}$ trans, CLA, $\mathrm{C}_{18: 1}$ trans-11, and $\mathrm{BOC}$ and a significant reduction of $\mathrm{C}_{18: 2 \mathrm{n}-6}, \mathrm{C}_{18: 3 n-3}$, and $\mathrm{C}_{18: 2}$ nonconjugated for the 100 and $200 \mu M$ treatments, whereas at $50 \mu M$ there was no significant difference from the control. However, there were significant linear increments of $\mathrm{C}_{18: 0}$ and $\mathrm{C}_{18: 1}$ trans and linear decrements of $\mathrm{C}_{18: 2 \mathrm{n}-6}, \mathrm{C}_{18: 3 \mathrm{n}-3}$, and $\mathrm{C}_{18: 2}$ nonconjugated with increasing

Table 4. $\mathrm{C}_{18}$ fatty acids and branched- and odd-chain (BOC) fatty acids (percentage of the total fatty acid content) in vessels after incubation with or without graded concentrations of 1,2-dimethylethyl hydroperoxide after $2 \mathrm{~h}$ (experiment 2$)$

\begin{tabular}{lcccccc}
\hline Item & Control & 50 & 100 & 200 & SED $^{1}$ & $\mathrm{~L}^{1}$ \\
\hline $\mathrm{C}_{18: 0}$ & 10.4 & 10.5 & $23.1^{\mathrm{a}}$ & $22.2^{\mathrm{a}}$ & 4.700 & $*$ \\
$\mathrm{C}_{18: 2 \mathrm{n}-6}$ & 9.35 & 9.05 & $6.59^{\mathrm{b}}$ & $5.98^{\mathrm{b}}$ & 1.029 & $*$ \\
$\mathrm{C}_{18: 3 \mathrm{n}-3}$ & 21.8 & 20.9 & $15.9^{\mathrm{b}}$ & $13.5^{\mathrm{b}}$ & 2.31 & $*$ \\
$\mathrm{C}_{18: 1}$ cis $^{2}$ & 5.68 & 5.91 & 4.54 & 4.94 & 0.627 & $*$ \\
$\mathrm{C}_{18: 1}$ trans $^{2}$ & 7.05 & 7.13 & $9.31^{\mathrm{a}}$ & $11.0^{\mathrm{a}}$ & 1.249 & $*$ \\
$\mathrm{C}_{18: 2}$ nonconjugated & 12.0 & 11.5 & $9.31^{\mathrm{b}}$ & $8.77^{\mathrm{b}}$ & 1.05 & \\
$\mathrm{CLA}^{2}$ & 0.60 & 0.43 & $0.74^{\mathrm{a}}$ & $0.81^{\mathrm{a}}$ & 0.133 & \\
$\mathrm{C}_{18: 1}$ trans-10 & 0.40 & 0.47 & 0.45 & 0.60 & 0.088 & \\
$\mathrm{C}_{18: 1}$ trans-11 & 4.74 & 4.18 & $5.82^{\mathrm{a}}$ & $6.28^{\mathrm{a}}$ & 0.716 & \\
CLA cis-9 trans-11 & 0.10 & $0.03^{\mathrm{b}}$ & 0.11 & 0.09 & 0.021 & \\
BOC & 4.4 & 6.5 & $6.3^{\mathrm{a}}$ & $7.3^{\mathrm{a}}$ & 0.136 & \\
\hline
\end{tabular}

${ }^{a}$ Values are greater $(P<0.05)$ than the control.

${ }^{b}$ Values are less $(P<0.05)$ than the control.

${ }^{1} \mathrm{SED}=$ standard error of the differences of means; $\mathrm{L}=$ linear effect of increasing concentration.

${ }^{2}$ Sum of all isomers.

$* P<0.05$. 
Table 5. $\mathrm{C}_{18}$ fatty acids and branched- and odd-chain (BOC) fatty acids (percentage of the total fatty acid content) in vessels after incubation with or without graded concentrations of 1,2-dimethylethyl hydroperoxide after $6 \mathrm{~h}$ (experiment 2)

\begin{tabular}{|c|c|c|c|c|c|c|}
\hline Item & Control & 50 & 100 & 200 & $\mathrm{SED}^{1}$ & $\mathrm{~L}^{1}$ \\
\hline $\mathrm{C}_{18: 0}$ & 43.0 & 43.9 & 43.6 & 44.2 & 0.471 & \\
\hline $\mathrm{C}_{18: 2 \mathrm{n}-6}$ & 4.02 & 3.77 & $3.56^{\mathrm{b}}$ & $3.32^{\mathrm{b}}$ & 0.190 & $*$ \\
\hline $\mathrm{C}_{18: 3 \mathrm{n}-3}$ & 12.1 & 11.1 & $10.9^{\mathrm{b}}$ & $9.7^{\mathrm{b}}$ & 0.562 & $*$ \\
\hline $\mathrm{C}_{18: 1}$ cis $^{2}$ & 4.99 & 4.92 & 4.95 & 5.20 & 0.122 & \\
\hline $\mathrm{C}_{18: 1}$ trans $^{2}$ & 6.42 & 6.86 & $7.25^{\mathrm{a}}$ & $7.76^{\mathrm{a}}$ & 0.746 & $*$ \\
\hline $\mathrm{C}_{18: 2}$ nonconjugated & 7.48 & 7.23 & $6.88^{\mathrm{b}}$ & $6.73^{\mathrm{b}}$ & 0.220 & \\
\hline $\mathrm{CLA}^{2}$ & 0.42 & 0.36 & 0.55 & 0.25 & 0.132 & \\
\hline $\mathrm{C}_{18: 1}$ trans -10 & 0.43 & 0.44 & $0.58^{\mathrm{a}}$ & $0.62^{\mathrm{a}}$ & 0.071 & $*$ \\
\hline $\mathrm{C}_{18: 1}$ trans -11 & 3.44 & 3.84 & $4.10^{\mathrm{a}}$ & $4.27^{\mathrm{a}}$ & 0.220 & $*$ \\
\hline CLA cis -9 , trans -11 & $\mathrm{ND}^{3}$ & ND & ND & ND & & \\
\hline $\mathrm{BOC}$ & 7.5 & 9.1 & 7.1 & 8.0 & 0.737 & \\
\hline
\end{tabular}

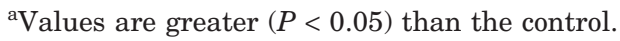

${ }^{\text {b}}$ Values are less $(P<0.05)$ than the control.

${ }^{1} \mathrm{SED}=$ standard error of the differences of means; $\mathrm{L}=$ linear effect of increasing concentration.

${ }^{2}$ Sum of all isomers. CLA = conjugated linoleic acid.

${ }^{3} \mathrm{ND}=$ not detected.

$* P<0.05$.

1,2-DMEH concentration in the incubations. After $6 \mathrm{~h}$ of incubation there was a total loss of CLA cis-9, trans11 and a net decrease of all fatty acids with the exception of marked increases in $\mathrm{C}_{18: 0}$ and BOC. The pattern of effects were similar to the $2 \mathrm{~h}$ incubations with the 100 and $200 \mu M$ treatments having significantly higher levels of $\mathrm{C}_{18: 1}$ trans and $\mathrm{C}_{18: 1}$ trans- 10 and trans -11 and significantly lower levels of $\mathrm{C}_{18: 2 \mathrm{n}-6}, \mathrm{C}_{18: 3 \mathrm{n}-3}$, and $\mathrm{C}_{18: 2}$ nonconjugated compared with the control incubations at $6 \mathrm{~h}$ with again the $50 \mu M$ having no significant effects. There were linear increases for the $\mathrm{C}_{18: 1}$ trans isomers and linear decreases of $\mathrm{C}_{18}$ PUFA with increasing 1,2-DMEH concentration. The final incubation time point $(24 \mathrm{~h})$ resulted in the highest concentrations of $\mathrm{C}_{18: 0}$ and $\mathrm{C}_{18: 1}$ trans and the lowest level of all other
$\mathrm{C}_{18}$ fatty acids. The BOC was also higher in the control and $50 \mu M$ treatments at $24 \mathrm{~h}$ but not in the 100 and $200 \mu M$ treatments. The difference across the treatments was less pronounced after $24 \mathrm{~h}$ with the only differences with 100 and $200 \mu M$ being increases in $\mathrm{C}_{18: 1}$ trans isomers, which were also linear with increasing 1,2-DMEH concentration. The $\mathrm{C}_{18}$ PUFA levels were not different across treatments and averaged 2.05 and $4.78 \%$ of fatty acids for $\mathrm{C}_{18: 2 \mathrm{n}-6}$ and $\mathrm{C}_{18: 3 \mathrm{n}-3}$, respectively.

To assess if 1,2-DMEH affected the total bacterial population, profiles of the bacterial community were generated using 16S rRNA-based DGGE. The similarity of the profiles obtained were compared and used to generate a cluster analysis dendrogram, which enabled

Table 6. $\mathrm{C}_{18}$ fatty acids and branched- and odd-chain (BOC) fatty acids (percentage of the total fatty acid content) in vessels after incubation with or without graded concentrations of 1,2-dimethylethyl hydroperoxide after $24 \mathrm{~h}$ (experiment 2)

\begin{tabular}{|c|c|c|c|c|c|c|}
\hline Item & Control & 50 & 100 & 200 & $\mathrm{SED}^{1}$ & $\mathrm{~L}^{1}$ \\
\hline $\mathrm{C}_{18: 0}$ & 65.0 & 63.3 & 64.2 & 67.1 & 1.35 & \\
\hline $\mathrm{C}_{18: 2 \mathrm{n}-6}$ & 2.13 & 2.25 & 1.95 & 1.88 & 0.219 & \\
\hline $\mathrm{C}_{18: 3 \mathrm{n}-3}$ & 4.74 & 5.63 & 4.50 & 4.25 & 0.751 & \\
\hline $\mathrm{C}_{18: 1} \mathrm{cis}^{2}$ & 4.15 & 4.15 & 4.41 & 4.48 & 0.281 & \\
\hline $\mathrm{C}_{18: 1}$ trans $^{2}$ & 9.19 & 10.6 & $11.2^{\mathrm{a}}$ & $12.5^{\mathrm{a}}$ & 0.697 & $*$ \\
\hline $\mathrm{C}_{18: 2}$ nonconjugated & 5.12 & 6.06 & 5.16 & 5.31 & 0.581 & \\
\hline $\mathrm{CLA}^{2}$ & 0.22 & 0.43 & 0.36 & 0.15 & 0.169 & \\
\hline $\mathrm{C}_{18: 1}$ trans -10 & 0.90 & 0.92 & $1.18 \mathrm{a}$ & $1.32 \mathrm{a}$ & 0.212 & * \\
\hline $\mathrm{C}_{18: 1}$ trans -11 & 3.88 & 4.76 & $4.93 \mathrm{a}$ & $5.05 \mathrm{a}$ & 0.478 & * \\
\hline CLA cis -9, trans -11 & ND & ND & ND & ND & & \\
\hline BOC & 8.3 & 11.1 & 7.2 & 6.1 & 2.85 & \\
\hline
\end{tabular}

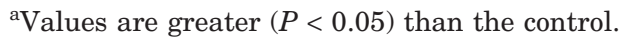

${ }^{1} \mathrm{SED}=$ standard error of the differences of means; $\mathrm{L}=$ linear effect of increasing concentration.

${ }^{2}$ Sum of all isomers.

$* P<0.05$. 


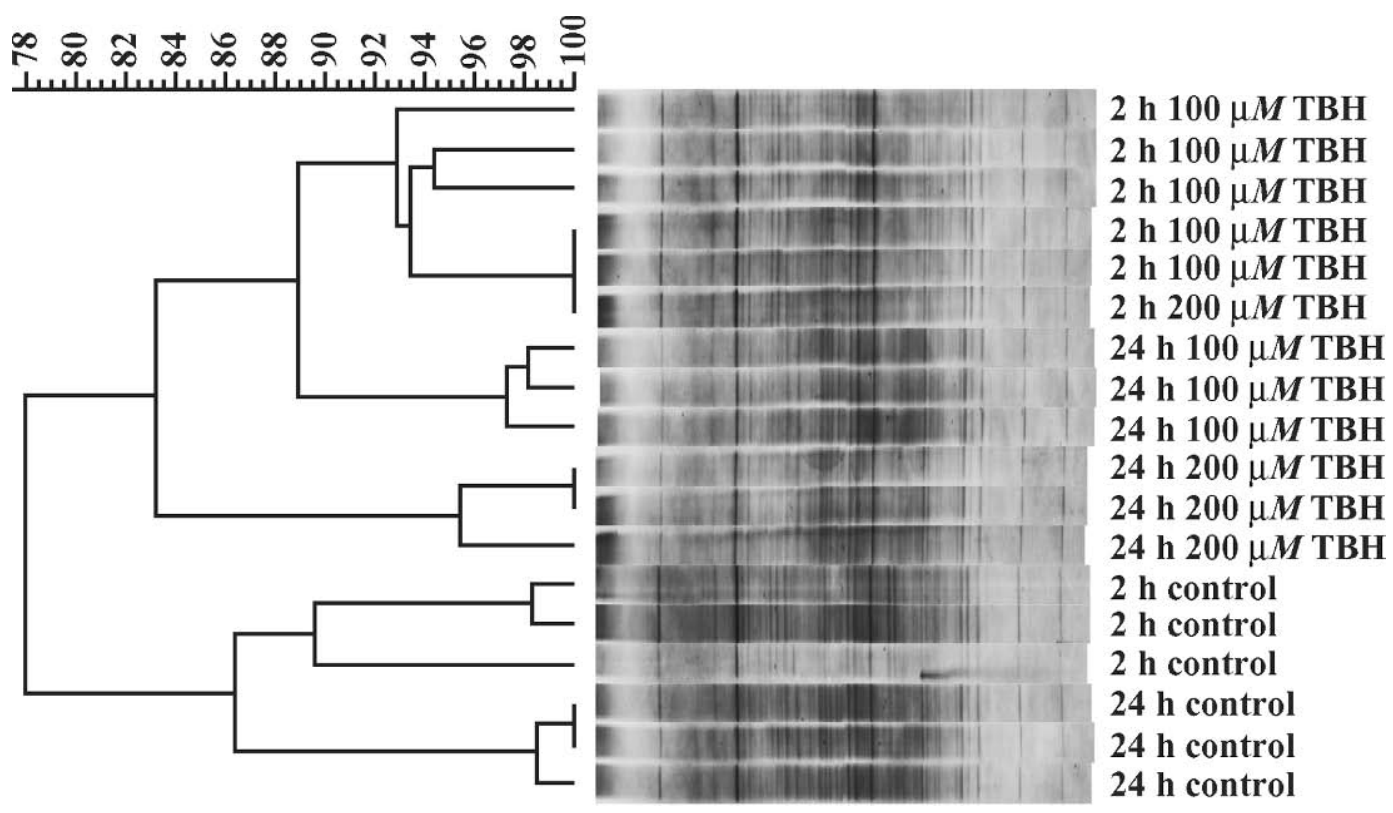

Figure 1. Denaturation gradient gel electrophoresis-derived unweighted pair group method with arithmetic mean dendrogram showing the effects of tert-butyl hydroperoxide/1,2-dimethylethyl hydroperoxide (TBH/1,2-DMEH) at concentrations of 100 and $200 \mu M$, and time intervals 2 and $24 \mathrm{~h}$, on the total eubacterial population. Scale $=\%$ similarity.

identification of samples with similar bacterial communities (Figure 1). All the control samples formed a distinct cluster separate from the treated samples, irrespective of time with $22 \%$ dissimilarity in bacterial consortia between addition and nonaddition of the FAOP. Within the cluster of treated samples, a difference in similarity was noted with FAOP concentration after 24 $\mathrm{h}$ of incubation. Therefore, it is clear that the FAOP at concentrations of 100 and $200 \mathrm{u} M$ caused distinct changes in the bacterial community at both time points and concentrations compared with controls, with a concentration dependent effect also noted after $24 \mathrm{~h}$ of treatment. Band number and Shannon-Weiner diversity index, which indicates total bacterial numbers (Table 7), did not differ significantly for any possible comparisons $(P>0.05)$.

Table 7. Band number and Shannon-Weiner diversity index calculated from the binary data obtained from the denaturation gradient gel electrophoresis profiles in the presence of no (control) and 100 and $200 \mu M$ 1,2-dimethylethyl hydroperoxide (1,2-DMEH; experiment 2)

\begin{tabular}{lclc}
\hline $\begin{array}{l}\text { Concentration } \\
\text { of 1,2-DMEH }\end{array}$ & $\begin{array}{c}\text { Time } \\
(\mathrm{h})\end{array}$ & $\begin{array}{c}\text { Band number } \\
( \pm \mathrm{SE})\end{array}$ & $\begin{array}{c}\text { Shannon-Weiner } \\
\text { diversity index } \\
\text { (evenness) }\end{array}$ \\
\hline Control & 2 & $25.67( \pm 4.16)$ & $3.44(0.92)$ \\
& 24 & $30.33( \pm 0.58)$ & $3.42(0.91)$ \\
100 & 2 & $26.33( \pm 1.53)$ & $3.35(0.89)$ \\
& 24 & $26.67( \pm 0.58)^{\mathrm{a}}$ & $3.28(0.87)$ \\
200 & 2 & $26( \pm 0)$ & $3.25(0.87)$ \\
& 24 & $22( \pm 0)^{\mathrm{a}}$ & $3.15(0.84)$ \\
\hline
\end{tabular}

${ }^{\text {aV }}$ alues are less $(P<0.05)$ than the control.

\section{DISCUSSION}

The 6 FAOP covered a range of hydroperoxide, aldehydes, ketone, and alcohol similar to those released from grasses after cutting to form the green odor of leaves (Hatanaka, 1993). The addition of HL or T2H had no effect on lipid metabolism in the incubation vessels compared with the control. The $\mathrm{C} 2 \mathrm{H}$ and $3 \mathrm{~B}$ affected some fatty acids, but these effects were relatively small and did not affect the biohydrogenation of $\mathrm{C}_{18: 2 \mathrm{n}-6}$ or $\mathrm{C}_{18: 3 \mathrm{n}-3}$. However, 1,2-DMEH and T2D both resulted in a significant increase in biohydrogenation with a consequent elevation in the biohydrogenation end-product and intermediate $\mathrm{C}_{18: 0}$ and $\mathrm{C}_{18: 1}$ trans- 11 , respectively. The 1,2-DMEH (Sriprang et al., 2000) and T2D (Kudo et al., 1995) have been shown to have antimicrobial properties, which may explain their mode of action in the present study. The degree of antimicrobial activity has been related to increasing chain length (Kudo et al., 1995) and saturation (Deng et al., 1993) of the FAOP, which may explain the lack of effect of either HL or T2H. In addition, Strobel et al. (2001) noted that the 4 classes of FAOP products had some inhibitory effect against bacterial growth; however, collectively they acted synergistically. Therefore in the present study, the effect of the FAOP may be underestimated or indeed masked due to the addition of individual FAOP.

Biohydrogenation of $\mathrm{C}_{18}$ PUFA on diets where the sole feed is fresh forage is extensive (Outen et al., 1975, 
Scollan et al., 2003). The current findings may suggest a role of FOAP in fresh forages in increasing the extent of biohydrogenation as incubations containing 1,2DMEH and T2D resulted in a more extensive biohydrogenation of $\mathrm{C}_{18}$ PUFA than for the control. However, Boufaied et al. (2003) reported a greater biohydrogenation of $\mathrm{C}_{18}$ PUFA when timothy was incubated in vitro as silage or haylage rather than as fresh grass. They also reported a greater production of $\mathrm{C}_{18: 1}$ trans in incubations containing timothy silage or haylage than with fresh grass in contrast to in vivo studies where fresh grass was grazed (Offer, 2002; Dewhurst et al., 2006). This anomaly may have been due to the stage of maturity of the harvested crop as Boufaied et al. (2003) also noted a significant reduction in biohydrogenation with increasing grass maturity. Maturity has also been related to a reduction in volatile release from cut orchardgrass associated with a reduction in the leafiness of the crop (Dohi et al., 1998). Therefore, more mature pasture may act similarly to conserved forage as a result of lower levels of green odor FAOP. In addition the flow of CLA cis-9, trans-11 is low in fresh forage-based studies with the majority of CLA cis-9, trans-11 in product (milk and meat) coming from the retro-conversion of $\mathrm{C}_{18: 1}$ trans-11 (Piperova et al., 2002). In the second experiment CLA cis-9, trans-11 was not found in the incubations after $6 \mathrm{~h}$ showing its transient nature in agreement with the findings of Scollan et al. (2003) who reported a lack of CLA in duodenal digesta in beef steers for an all-grass diet.

Green odor FAOP and similar products can also be found in other oxidized lipids, which may be fed to ruminants. Vazquez-Anon et al. (2006) reported similar effects on lipid metabolism with shifts in $\mathrm{C}_{18}$ PUFA biohydrogenation when oxidized fat was added to in vitro incubations containing rumen liquor. Similar compounds are also found within fish oil (Aidos et al., 2002), which may explain the rise in $\mathrm{C}_{18: 1}$ trans-10 in the current study particularly with $3 \mathrm{~B}$ and 1,2-DMEH because this particular $\mathrm{C}_{18: 1}$ intermediate has been shown to be associated with supplementation of fish oil to ruminants (Wasowska et al., 2006). This switch in $\mathrm{C}_{18: 1}$ isomers with fish oil is associated with a reduction in the final conversion of $\mathrm{C}_{18: 1}$ trans- 11 to $\mathrm{C}_{18: 0}$ through a proposed inhibition of the group $\mathrm{B}$ bacteria. It is possible that FAOP products in fish oil have a role in biohydrogenation through an antimicrobial activity toward group B bacteria.

Certain BOC fatty acids associated with microbial lipid and used as microbial markers $\left(\mathrm{C}_{15: 0}\right.$ iso, $\mathrm{C}_{15: 0}$ anteiso, $\mathrm{C}_{17: 0}$ iso, and $\mathrm{C}_{17: 0}$ anteiso; Kim et al., 2005) were significantly reduced when 1,2-DMEH or T2D were added in the first experiment. A reduction in microbial lipid may also explain the reduction in $\mathrm{C}_{12: 0}$,
$\mathrm{C}_{14: 0}$, and $\mathrm{C}_{16: 0}$ when these FAOP were added to the vessel because these fatty acids are also major components of microbial lipid (Merry and MacAllan, 1983). This mode of action was investigated in the second experiment with the use of 1,2-DMEH at 3 concentrations and 3 time points. Indeed, DGGE-unweighted pair group method with arithmetic mean dendrograms (Figure 1) revealed that 1,2-DMEH at concentrations of 100 and $200 \mu M$ did change the microbial community from the control. This effect was apparent as soon as $2 \mathrm{~h}$ after addition. Concurrent changes in the lipid profiles were also apparent after $2 \mathrm{~h}$ in agreement with experiment 1 with significant linear rises in biohydrogenation intermediates $\mathrm{C}_{18: 1}$ trans, $\mathrm{C}_{18: 2}$ nonconjugated, the endproduct $\mathrm{C}_{18: 0}$, and the microbially derived BOC. There was also a linear reduction in $\mathrm{C}_{18}$ PUFA. After $6 \mathrm{~h}$, the difference in $\mathrm{C}_{18: 0}$ and $\mathrm{BOC}$ was lost across treatments, and at $24 \mathrm{~h}$ there were no significant differences in $\mathrm{C}_{18}$ PUFA in the incubations. This may be related to the transient nature of the FAOP volatiles because the in vitro incubations did not simulate a replenishment of volatiles as would occur with ruminant grazing naturally. The BOC in the vessels in experiment 2 were not as affected by the addition of 1,2-DMEH as in experiment 1 , and band number and Shannon Weiner diversity indices showed very little difference between control and test values in bacterial numbers. Nonetheless, following $24 \mathrm{~h}$, band numbers were significantly lower after the addition of 100 and $200 \mu M$ of 1,2-DMEH. Indeed numerous studies have shown a selectivity of antimicrobial activity of FAOP (Kubo, 1993; Rocha et al., 1996), which may explain this effect on biohydrogenation by selective inhibition of bacterial species reducing interspecific competition for the biohydrogenating species and so altering the microbial consortia (Figure 1) while maintaining bacterial number (Table 7).

\section{CONCLUSION}

These preliminary studies have shown that FAOP can affect fatty acid biohydrogenation. This may provide a partial explanation for the increased flow of $\mathrm{C}_{18: 1}$ trans-11 from the rumen of ruminants grazing fresh pasture and the subsequent elevation in milk CLA cis9, trans- 11 .

\section{ACKNOWLEDGMENTS}

The financial support of the EU (project QLK1-200202362 BIOCLA) and the UK Department of the Environment Food and Rural Affairs. The authors acknowledge and thank the skilled technical assistance of John K. S. Tweed and Margaret Neville and the staff at Trawsgoed Research Farm. 


\section{REFERENCES}

Aidos, I., C. Jacobsen, B. Jensen, J. B. Luten, A. van der Padt, and R. M. Boom. 2002. Volatile oxidation products formed in crude herring oil under accelerated oxidative conditions. Eur. J. Lipid Sci. Technol. 104:808-818.

Boufaied, H., P. Y. Chouinard, G. F. Trembley, H. V. Petit, R. Michaud, and G. Belanger. 2003. Fatty acids in forages. II. In vitro ruminal biohydrogenation of linolenic and linoleic acids from timothy. Can. J. Anim. Sci. 83:513-522.

Cho, M. J., R. W. Buescher, M. Johnson, and M. James. 2004. Inactivation of pathogenic bacteria by cucumber volatiles $(E, Z)-2,6$-nonadienal and (E)-2-nonenal. J. Food Prot. 67:1014-1016.

Creelman, R. A., and J. E. Mullet. 1997. Biosynthesis and action of jasmonates in plants. Annu. Rev. Plant Physiol. Mol. Biol. 48:355-381.

Demeyer, D., and M. Doreau. 1999. Targets and procedures for altering ruminant meat and milk lipids. Proc. Nut. Soc. 58: 593-607.

Deng, W. L., T. R. Hamilton-Kemp, M. T. Nielsen, R. A. Andersen, G. B. Collins, and D. F. Hiderbrand. 1993. Effects of 6-carbon aldehydes and alcohols on bacterial proliferation. J. Agric. Food Chem. 41:506-510.

Dewhurst, R. J., R. T. Evans, N. D. Scollan, J. M. Moorby, R. J. Merry, and R. J. Wilkins. 2003. Comparisons of grass and legume silages for milk production. 2. In vivo and in sacco evaluations of rumen function. J. Dairy Sci. 86:2612-2621.

Dewhurst, R. J., K. J. Shingfield, M. R. F. Lee, and N. D. Scollan. 2006. Increasing the concentrations of beneficial polyunsaturated fatty acids in milk produced by dairy cows in high-forage systems. Anim. Feed Sci. Technol. 131:168-206.

Dohi, H., M. Kazuhiko, and A. Yamada. 1998. A comparison of volatile chemicals from Orchardgrass (Dactylis glomerata L.) varieties with different palatabilities. Grassl. Sci. 44:185-188.

Feussner, I., and C. Wasternack. 2002. The lipoxygenase pathway. Annu. Rev. Plant Biol. 53:275-297.

Gafan, G. P., V. S. Lucas, G. J. Roberst, A. Petrie, M. Wilson, and D. A. Spratt. 2005. Statistical analyses of complex denaturing gradient gel electrophoresis profiles. J. Clin. Microbiol. 43:3971-3978.

Hatanaka, A. 1993. The biogeneration of green odour by green leaves. Phytochemistry 34:1201-1218.

Heilig, H., E. G. Zoetendal, E. Vaughan, P. Marteau, A. Akkermans, and W. de Vos. 2002. Molecular diversity of Lactobacillus spp. and other lactic acid bacteria in the human intestine as determined by specific amplification of 16S ribosomal DNA. Appl. Environ. Microbiol. 68:114-123.

Kemp, P., and D. J. Lander. 1984. Hydrogenation in vitro of $\alpha$-linolenic acid to stearic acid by mixed cultures of pure strains of rumen bacteria. J. Gen. Microbiol. 130:527-533.

Kepler, C. R., W. P. Tucker, and S. B. Tove. 1970. Biohydrogenation of unsaturated fatty acids. IV. Substrate specificity and inhibition of linolenate $\Delta 12$-cis, $\Delta 11$-trans-isomerase from Butyrivibrio fibrisolvens. J. Biol. Chem. 245:3612-3620.

Kim, E. J., R. Sanderson, M. S. Dhanoa, and R. J. Dewhurst. 2005. Fatty acid profiles associated with microbial colonization of freshly-ingested grass and rumen biohydrogenation. J. Dairy Sci. 88:3220-3230.

Kirstine, W., I. E. Galbally, Y. Ye, and M. A. Hooper. 1998. Emissions of volatile organic compounds (primarily oxygenated species) from pasture. J. Geophys. Res. 103:10605-10619.

Kramer, J. K. G., and J. Zhou. 2001. Conjugated linoleic acid and octadecenoic acids: Extraction and isolation of lipids. Eur. J. Lipid Sci. Technol. 103:600-609.

Kubo, I. 1993. Antimicrobial activity of green tea flavour components-Effectiveness against streptococcus-mutans. ACS Symp. Ser. 525:57-70.

Kudo, A., C. S. Lunde, and I. Kubo. 1995. Antimicrobial activity of the olive oil flavour compounds. J. Agric. Good Chem. 43:1629-1633.

Lee, M. R. F., A. L. Winters, N. D. Scollan, R. J. Dewhurst, M. K. Theodorou, and F. R. Minchin. 2004. Plant mediated lipolysis and proteolysis in red clover with different polyphenol oxidase activities. J. Sci. Food Agric. 84:1639-1645.

Lock, A. L., and D. E. Bauman. 2004. Modifies milk fat composition of dairy cows to enhance fatty acids beneficial to human health. Lipids 39:1197-1206.

Merry, R. J., and A. B. MacAllan. 1983. A comparison of the chemical composition of mixed bacteria harvested from liquid and solid fraction of rumen digesta. Br. J. Nutr. 50:701-709.

Nübel, U., B. Engelen, A. Felske, J. Snaidr, A. Wieshuber, R. I. Amann, W. Ludwig, and H. Backhaus. 1996. Sequence heterogeneities of genes encoding 16S rRNAs in Paenibacillus polymyxa detected by temperature gradient gel electrophoresis. J. Bac. 178:5636-5643.

Offer, N. W. 2002. Effect of cutting and ensiling grass on levels of CLA in bovine milk. Pages 16-17 in The XIIIth Int. Silage Conf., Auchincruive, Scotland.

Outen, G. E., D. E. Beever, D. F. Osbourn, and D. J. Thomson. 1975. The digestion of lipids of processed red clover herbage by sheep. J. Sci. Food Agric. 26:1381-1389.

Payne, R. W., D. A. Murray, S. A. Harding, D. B. Baird, and D. M Soutar. 2002. Genstat ${ }^{\circledR}$ for Windows ${ }^{\mathrm{TM}}$. 8th ed. Introduction. VSN Int., Oxford, UK.

Piperova, L. S., L. Sampugna, B. B. Teter, K. F. Kalscheur, M. P. Yurawecz, Y. Ku, K. M. Moorehouse, and R. A. Erdman. 2002. Duodenal and milk trans octadecenoic acid and conjugated linoleic acid (CLA) isomers indicate that postabsorptive synthesis is the predominant CLA in lactating dairy cows. J. Nutr. 132:1235-1241.

Rocha, E. R., T. Selby, J. P. Coleman, and C. J. Smith. 1996. Oxidative stress responses in an anaerobic, Bacteroides fragilis: A role for catalase in protection against hydrogen peroxide. J. Bacteriol. 178:6895-6903.

Rusterucci, C., J.-L. Montillet, J.-P. Agnel, C. Battesti, B. Alonso, A. Knoll, J.-J. Bessoule, P. Etienne, L. Suty, and J.-P. Blein. 1999. Involvement of lipoxygenases-dependant production of fatty acid hydroperoxides in the development of the hypersensitive cell death induced by cryptogein of tobacco leaves. J. Biol. Chem. 274:36446-36455.

Sanguinetti, C. J., E. Dias Neto, and A. J. Simpson. 1994. Rapid silver staining and recovery of PCR products separated on polyacrylamide gels. Biotechniques 17:914-921.

Scollan, N. D., M. R. F. Lee, and M. Enser. 2003. Biohydrogenation and digestion of long chain fatty acids in beef steers fed on Lolium perenne bred for elevated levels of water-soluble carbohydrate. Anim. Res. 53:501-511.

Sriprang, R., P. Vattanaviboon, and S. Mongkolsuk. 2000. Exposure of phytopathogenic Xanthomonas spp. to lethal concentrations of multiple oxidants affects bacterial survival in a complex manner. Appl. Environ. Microbiol. 66:4017-4021.

Strobel, G. A., E. Dirkse, J. Sears, and C. Markworth. 2001. Volatile antimicrobials from Muscodor albus, a novel endophytic fungus. Microbiology 147:2934-2950.

Sukhija, P. S., and D. L. Palmquist. 1988. Rapid method for the determination of total fatty acid content and composition of feedstuff and feces. J. Agric. Food Chem. 36:1202-1206.

Thaler, J. 1999. Jasmonate-inducible plant defences cause increased parasitism of herbivores. Nature 399:686-688.

Thomas, H. 1986. The role of polyunsaturated fatty acids in senescence. J. Plant Physiol. 123:97-105.

Vazquez-Anon, M., J. Andrews, T. Webster, and T. Jenkins. 2006. Effects of feeding oxidised fat supplemented with antioxidant AGRADO on rumen nutrient digestibility and protein synthesis. J. Dairy Sci. 89(Suppl. 1):406.

Wasowska, I., M. R. G. Maia, K. M. Niedzwiedzka, M. Czauderna, J. M. C. Ramalho Ribeiro, E. Devillard, K. J. Shingfield, and R. J. Wallace. 2006. Influence of fish oil on ruminal biohydrogenation of C18 unsaturated fatty acids. Br. J. Nutr. 95:1199-1211.

Yu, Z., and M. Morrison. 2004. Comparisons of different hypervariable regions of rrs genes for use in fingerprinting of microbial communities by PCR-denaturing gradient gel electrophoresis. Appl. Environ. Microbiol. 70:4800-4806. 